\title{
IS7 I I-based real-time PCR assay as a tool for detection of Brucella spp. in wild boars and comparison with bacterial isolation and serology
}

\author{
Vladimira Hinićc ${ }^{1}$, Isabelle Brodard ${ }^{1}$, Andreas Thomann ${ }^{1}$, Milena Holub ${ }^{1}$, \\ Raymond Miserez ${ }^{2}$ and Carlos Abril*1
} \begin{abstract}
Tiergesundheit, Planaterrastrasse 11, 7001 Chur, Switzerland
Email: Vladimira Hinić - vladimira.hinic@vbi.unibe.ch; Isabelle Brodard - isabelle.brodard@vbi.unibe.ch; Andreas Thomann - andreas.thomann@vbi.unibe.ch; Milena Holub - milena.holub@vbi.unibe.ch;

Raymond Miserez - raymond.miserez@alt.gr.ch; Carlos Abril* - carlos.abril@vbi.unibe.ch

* Corresponding author
\end{abstract}

Address: ${ }^{1}$ National Centre for Zoonoses, Bacterial Animal Diseases and Antimicrobial Resistance (ZOBA), Institute of Veterinary Bacteriology, University of Bern, Vetsuisse Faculty, Länggass-Strasse 122, PO Box, CH-3001 Bern, Switzerland and 2Amt für Lebensmittelsicherheit und

Published: 14 July 2009

BMC Veterinary Research 2009, 5:22 doi:10.1186/1746-6/48-5-22

This article is available from: http://www.biomedcentral.com//746-6/48/5/22

(c) 2009 Hinić et al; licensee BioMed Central Ltd.

This is an Open Access article distributed under the terms of the Creative Commons Attribution License (http://creativecommons.org/licenses/by/2.0), which permits unrestricted use, distribution, and reproduction in any medium, provided the original work is properly cited.

\begin{abstract}
Background: Control of brucellosis in livestock, wildlife and humans depends on the reliability of the methods used for detection and identification of bacteria. In the present study, we describe the evaluation of the recently established real-time PCR assay based on the Brucella-specific insertion sequence IS7 I I with blood samples from 199 wild boars (first group of animals) and tissue samples from 53 wild boars (second group of animals) collected in Switzerland. Results from IS7 I I real-time PCR were compared to those obtained by bacterial isolation, Rose Bengal Test (RBT), competitive ELISA (c-ELISA) and indirect ELISA (i-ELISA).

Results: In the first group of animals, IS7II real-time PCR detected infection in II.I\% (I6/I44) of wild boars that were serologically negative. Serological tests showed different sensitivities [RBT $15.6 \%$, c-ELISA $7.5 \%$ and i-ELISA $5.5 \%$ ] and only $2 \%$ of blood samples were positive with all three tests, which makes interpretation of the serological results very difficult. Regarding the second group of animals, the IS7 II real-time PCR detected infection in $26 \%$ of animals, while Brucella spP. could be isolated from tissues of only $9.4 \%$ of the animals.
\end{abstract}

Conclusion: The results presented here indicate that IS7 I / real-time PCR assay is a specific and sensitive tool for detection of Brucella spp. infections in wild boars. For this reason, we propose the employment of IS7I I real-time PCR as a complementary tool in brucellosis screening programs and for confirmation of diagnosis in doubtful cases.

\section{Background}

Brucellosis is a widespread zoonosis of great economic importance caused by facultative intracellular Gram-negative bacteria belonging to the genus Brucella. Although brucellosis in domestic animals has been eradicated in great number of European countries, the risk of reintroduction of the disease still exists through spill-over from wildlife that are considered to be natural reservoirs [1]. A 
study on the surveillance of different swine pathogens demonstrated the presence of Brucella suis biovar 2 in a population of wild boars in Switzerland $[2,3]$.

Reliable and sensitive diagnostic tools play a crucial role in the control of brucellosis in livestock, wildlife and humans. Although blood and tissue cultures remain the 'gold standard' for diagnosis, they show low sensitivity, are time consuming, and represent a risk for laboratory personnel $[4,5]$.

Serology is a standard method for the epidemiological surveillance of brucellosis [2,3,6-9]. However, cross-reactions between Brucella species and other Gram-negative bacteria, such as Yersinia enterocolitica O:9, Francisella tularensis, Escherichia coli O:157, Salmonella urbana group N, Vibrio cholerae and Stenotrophomonas maltophilia, are a major problem of the serological assays [10-13]. The source of antigenic cross-reactions is the O-chain of the smooth lipopolysaccharide (S-LPS) present on the surface of the bacterial cell, which shows great similarity in smooth Brucella spp. and the abovementioned bacteria [14]. False-positive serological results due only to $Y$. enterocolitica O:9 affect up to $15 \%$ of the cattle herds in regions free from brucellosis, generating considerable additional costs for surveillance programs [13]. False-negative results have also been observed in serological diagnosis of brucellosis [11,15-17]. They occur mostly due to the fact that the antibody response is dependent upon the stage of infection during sample collection [18]. For example, Leal-Klevezas and colleagues stated that detectable amounts of antibodies are not recorded in the first 12-16 days after artificial inoculation of goats with Brucella abortus [19]. On the other hand, when the disease becomes chronic, the antibody titre could fall to undetectable levels $[17,20]$, which is especially the case with intracellular organisms like Brucella spp. [21]. Latent infection without seroconversion further complicates the problem, particularly in pre-pubertal animals [22].

Molecular diagnostic techniques represent an important breakthrough in the diagnostic practice. A number of genus- or species-specific conventional PCR assays using primers derived from different gene sequences from the Brucella genome, such as 16S rRNA [23], the 16S-23S intergenic spacer region [24], omp2 [25] and bcsp31 [26], have been established. These assays were adapted for application to Brucella detection in different clinical specimens. In the majority of studies, conventional PCR proved to be a good means to detect Brucella DNA from clinical specimens [27-35], while Romero and colleagues found that PCR had lower sensitivity compared to the conventional detection methods [36].

The introduction of real-time PCR offers improved sensitivity, specificity and speed of performance compared with conventional PCR. Several real-time PCR assays using different detection chemistries have already been established for Brucella identification [37-39]. Moreover, some of them were evaluated with various clinical samples of human and animal origins [40-45]. Most of the authors confirmed that real-time PCR was a very sensitive method of detection from clinical samples [41,43,44]; nevertheless, O'Leary and colleagues found that there was no advantage in using real-time PCR on blood, milk and lymph node samples of naturally infected cows over standard serological and bacteriological methods [45].

The goal of our present study was to evaluate the performance of a recently described real-time PCR assay [46] for Brucella spp. detection with wild boar blood and tissue samples collected under the wild boar surveillance program in Switzerland. This assay is based on the Brucella spp. specific multiple IS711 insertion sequence and therefore shows great sensitivity [46]. The same samples were additionally tested by bacterial isolation and three serological tests (i-ELISA, c-ELISA and RBT), and the results obtained were compared to those of the real-time PCR.

\section{Results \\ Bacteriological isolation}

There were no differences in the results obtained with bacteriological isolation before and after freezing of the tissue samples. Brucella was isolated from tissue samples of 5 (9.4\%) out of 53 animals (Table 1). According to the bacterial isolation method, the highest prevalence was found in tissues of reproductive organs (three isolates in uterus, one in accessory sexual glands, one in preputium). Brucella was also isolated from one spleen and one lung sample. All Brucella strains were identified as B. suis biovar 2 . Table 2 shows the detection of Brucella spp. in individual tissue samples by bacterial isolation and IS711 real-time PCR. In three animals, bacterial colonies with morphological characteristics similar to Brucella spp. were isolated. Their lysates tested negative with the IS711 real-time PCR assay and were subsequently submitted for 16S rRNA gene sequence analysis. The sequence showed 99\% identity with Bisgaard Taxon 10 (Pasteurellaceae).

No Brucella bacteria could be isolated from blood samples.

Table I: Detection of Brucella spp. in tissue samples by bacterial isolation and IS7 I I real-time PCR from wild boars.

\begin{tabular}{llll}
\hline & & \multicolumn{2}{l}{ Positive samples } \\
\cline { 3 - 4 } Method & Number of animals & No. & $\%$ \\
\hline Bacterial isolation & 53 & 5 & 9.4 \\
IS7I I real-time PCR & 53 & 14 & 26
\end{tabular}


Table 2: Detection of Brucella spp. in tissue samples by bacterial isolation and IS7 II real-time PCR.

\begin{tabular}{|c|c|c|c|c|c|c|c|c|c|c|}
\hline \multirow[b]{3}{*}{$\begin{array}{l}\text { Positive } \\
\text { Animal }\end{array}$} & \multicolumn{8}{|c|}{ Tissue samples } & & \\
\hline & \multicolumn{2}{|c|}{ Spleen } & \multicolumn{2}{|c|}{ Acc. sex glands } & \multicolumn{2}{|c|}{ Testicles } & \multicolumn{2}{|c|}{ Uterus } & \multicolumn{2}{|c|}{ Other } \\
\hline & $\begin{array}{l}\text { Bact. } \\
\text { Isolation }\end{array}$ & $\begin{array}{l}\text { IS7II RT- } \\
\text { PCR }\end{array}$ & $\begin{array}{l}\text { Bact. } \\
\text { isolation }\end{array}$ & $\begin{array}{l}\text { IS7II RT- } \\
\text { PCR }\end{array}$ & $\begin{array}{l}\text { Bact. } \\
\text { isolation }\end{array}$ & $\begin{array}{l}\text { IS7II RT- } \\
\text { PCR }\end{array}$ & $\begin{array}{l}\text { Bact. } \\
\text { isolation }\end{array}$ & $\begin{array}{l}\text { IS7II RT- } \\
\text { PCR }\end{array}$ & $\begin{array}{l}\text { Bact. } \\
\text { isolation }\end{array}$ & $\begin{array}{l}\text { IS7III RT- } \\
\text { PCR }\end{array}$ \\
\hline 1 & + & + & & & & & + & + & & \\
\hline 2 & - & + & + & + & - & + & & & $+a$ & $+a$ \\
\hline 3 & - & + & & & & & + & + & & \\
\hline 4 & - & + & - & + & - & + & & & & \\
\hline 5 & - & + & & & & & - & + & $+b$ & $+b$ \\
\hline 6 & - & - & & & & & - & + & & \\
\hline 7 & - & - & & & & & - & + & & \\
\hline 8 & - & + & & & - & + & & & & \\
\hline 9 & - & + & & & & & & & $-c$ & $+c$ \\
\hline 10 & - & + & - & + & - & + & & & & \\
\hline 11 & - & - & - & + & - & - & & & & \\
\hline 12 & - & + & - & + & - & + & & & $-d$ & $+d$ \\
\hline 13 & - & + & & & & & + & + & & \\
\hline 14 & - & + & - & + & - & + & & & & \\
\hline
\end{tabular}

a Preputium

b Lungs

c Placenta

d Urine

\section{Serological testing}

Sera from 199 animals were tested with 3 different serological methods. RBT showed the highest sensitivity, detecting 31 (15.6\%) positive samples while results could not be obtained for 4 (2\%) samples due to strong haemolysis. With the c-ELISA, 15 (7.5\%) samples tested positive. i-ELISA detected 11 (5.5\%) positive samples, while 6 (3\%) samples showed equivocal results. Table 3 summarises the results of the different methods used for testing the blood samples. Only 4 (2\%) samples were found positive with all 3 serological tests. Figure 1 and Table 4 show the comparative analysis of positive samples detected with both serology and IS711 real-time PCR.

\section{Testing of tissue samples with IS7 I I real-time PCR}

The signal for $18 \mathrm{~S}$ rRNA gene (endogenous extraction control) was detected for all samples. By testing tissue samples originating from 53 wild boars, all 5 positive
$(9.4 \%)$ animals detected by bacterial isolation were also detected by IS711 real-time PCR. Furthermore, with the IS711 real-time PCR, we were able to additionally detect nine $(17 \%)$ infected animals that were negative by the bacterial isolation method. Interestingly, in 10 out of 14 positive animals, IS711 real-time PCR was able to detect Brucella-specific DNA in every organ that was available for examination. Table 1 shows the number of positive animals detected by bacterial isolation and IS711 real-time PCR. Table 2 shows the detection of Brucella spp. in individual tissue samples by bacterial isolation and IS711 realtime PCR. The quantification of bacteria per host cell in various organs revealed that of the 14 real-time PCR positive animals, 11 of them had the largest quantities of Brucella DNA in sexual organs (uterus, uterine fluid, testicle or accessory sexual gland), ranging up to 8081 IS711 copies pro 1000 cells. In two animals the spleen was principally affected ( 7 and 74.5 IS711 copies pro 1000 cells),

Table 3: Results of different methods for Brucella spp. diagnosis from blood samples in wild boars.

\begin{tabular}{|c|c|c|c|c|c|c|c|}
\hline \multirow[b]{2}{*}{ Method } & \multirow[b]{2}{*}{ Total Samples } & \multicolumn{2}{|c|}{ Positive samples detected } & \multicolumn{2}{|c|}{ Equivocal samples } & \multicolumn{2}{|c|}{ No result ${ }^{\mathrm{a}}$} \\
\hline & & No. & $\%$ & No. & $\%$ & No. & $\%$ \\
\hline i-ELISA & 199 & 11 & 5.5 & 6 & 3 & & \\
\hline c-ELISA & 199 & 15 & 7.5 & & & & \\
\hline RBT & 199 & 31 & 15.6 & & & 4 & 2 \\
\hline IS7II real-time PCR & 199 & 27 & 13.6 & & & 9 & 4.5 \\
\hline
\end{tabular}

a The results could not be obtained for four samples tested with RBT due to strong haemolysis, and for nine samples tested with IS7II real-time PCR because of inhibition caused by their poor quality 


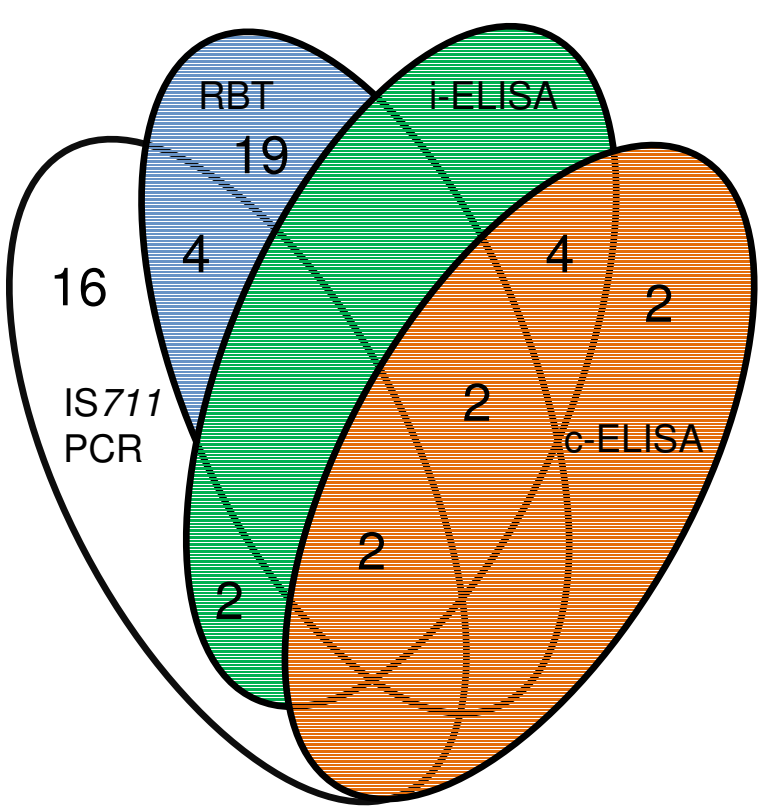

Figure I

Venn diagram showing a summary of serological (RBT, c-ELISA and i-ELISA) and IS7 I I real-time PCR results for blood samples from wild boars. Footnote: In order to simplify the comparison, the six equivocal samples in i-ELISA, four blood samples for which the result was not obtained with RBT, and nine samples inhibited in the realtime PCR were not included in the comparison (total number of blood samples included into the comparison analysis $n=180)$.

whereas in only one animal the largest Brucella DNA quantity was found in urine (2.5 IS711 copies pro 1000 cells).

\section{Testing of blood samples with IS7 I I real-time PCR}

As already mentioned, only leukocyte pellets were used for DNA extraction from blood samples. In 9 out of 199 (4.5\%) samples, results were not obtained with the realtime PCR due to inhibition caused by the poor quality of the given blood samples. The signal for 18S rRNA gene (endogenous extraction control) was detected for all samples, except the nine aforementioned samples that were inhibited. Out of 199 blood samples, 27 (13.6\%) tested positive with the IS711 real-time PCR. Surprisingly, IS711 real-time PCR detected infection in $11.1 \%(16 / 144)$ of wild boars that were serologically negative. Table 3 summarises the results of the different methods used for testing blood samples.

\section{Discussion}

In this study, we report the performance of the recently described real-time PCR assay for the detection of Brucella spp. [46] in blood and tissue samples from naturally infected wild boars. Results obtained were compared with the results of bacterial isolation and three different serological tests for detection of brucellosis: RBT, i-ELISA and c-ELISA. This real-time PCR assay is very appealing as a diagnostic tool because it targets the IS711 insertion element, which is present in multiple copies in Brucella genomes and at the same time represents a stable genetic element with respect to number and positions in the genomes of various Brucella species [47,48]. The IS711 real-time PCR assay has been shown to be specific for Brucella spp. with a detection limit of 10 copies, indicating high assay sensitivity [46].

Regarding Brucella spp. detection in wild boar tissue samples, the IS711 assay was able to additionally detect Brucella DNA in tissues of $9(17 \%)$ animals that were negative by bacterial isolation (Table 1 and 2). This low sensitivity of the culture method has already been reported by different authors $[4,5]$. The significantly higher detection sensitivity of real-time PCR can be explained by the fact that it detects DNA from bacteria that are damaged and nonviable and therefore impossible to isolate by conventional cultures. In 10 out of 14 real-time PCR positive animals, the IS711 real-time PCR assay was able to detect Brucella DNA from almost every organ that was submitted for examination (Table 2). The quantification of bacteria per host cell in various organs revealed that in 11 of the realtime PCR positive animals, the largest quantities of Brucella DNA were found in sexual organs, in two animals the spleen was principally affected, whereas in only one animal the largest Brucella DNA quantity was found in urine. These differences probably correlated with the stage of infection in individual animals. Since the samples at our disposition originated from animals shot by hunters, it was impossible to compare the variation in sensitivity of the different methods during the course of infection, according to clinical status or age.

No Brucella bacteria could be isolated from blood samples. This is in concordance with the reports of other authors stating that recovery of the bacteria by blood and milk culture is insensitive [19].

In contrast, IS711 real-time PCR was able to detect Brucella DNA in 27 (13.6\%) out of 199 blood samples (Table $3)$. It is relevant to mention that the PCR performance with the Brucella DNA extracted from blood samples is very often compromised by the presence of PCR inhibitors and further complicated because Brucella is an intracellular pathogen [27]. However, the protocols presented here make detection of Brucella DNA from blood samples more feasible because only the leukocyte pellet was used for DNA extraction. Although it was reported that high concentrations of leukocyte DNA could inhibit the PCR assay [49], the IPC (internal positive control) signal was 
detected for all samples used in this assay except for nine samples, which were inhibited due to poor blood sample quality.

It is interesting to remark the discrepancies with the serological results. Comparing serology with the results of the IS711 assay, only $2(1.1 \%)$ out of 180 samples included in the comparative analysis were positive with all serological tests and IS711 real-time PCR (Figure 1 and Table 4). Interestingly, IS711 real-time PCR detected infection in $11.1 \%(16 / 144)$ of the seronegative wild boars (Figure 1 and Table 4), which prompts us to conclude that these were probably acute or chronically infected animals with antibody levels beyond the detectable limit. Latent infection without seroconversion further complicates the problem, particularly in pre-pubertal animals [22]. While PCR directly detects the DNA of the pathogen, the serology is dependent upon the variable titres of antibodies in different phases of the disease [18]. On the other hand, $18 \%$ (28/156) of IS711 real-time PCR negative samples were seropositive in our study, which could be either due to a lack of sensitivity of the real-time PCR technique or serological false positives. Keeping in mind the well documented problem of extensive serological cross-reactions with other bacteria $[10,12,13,22]$, it is highly likely that a great number of these samples were indeed false positives. Further difficulties associated with serological testing in wildlife is the fact that most tests have been directly transposed, without validation, from their use in domestic animals to the wild species, even though they may not perform identically [22].

In summary, in this study, the IS711 real-time PCR was able to increase the number of positive animals which were negative by bacterial isolation and detect additional positive animals that were seronegative. Moreover, not all the seropositive animals were detected positive by the IS711 real-time PCR. Therefore, it is important to use more than one type of diagnostic techniques for the detection of brucellosis in animals, which is an issue that has already been addressed by different authors $[50,51]$.

\section{Conclusion}

The IS711 assay described here is a sensitive and specific method for detection of Brucella spp. in blood and tissue specimens of wild boars. Since the data on prevalence of brucellosis in wild boar populations is still being estimated by serology $[2,3,6-9]$, we are of the opinion that this assay should be included in brucellosis screening programs in order to complement the drawbacks of the conventional detection methods. Additionally, this assay should also be a method of choice for diagnosis of brucellosis in various wild and zoo animals, considering that current serological tests are evaluated only for domestic animals.

\section{Methods}

\section{Study design and collection of clinical specimens}

The clinical material to be tested in this study originated from a population of wild boars in Switzerland that, as demonstrated by Leuenberger and colleagues, represents a natural reservoir of Brucella suis biovar 2 [2]. The tissue and blood samples collected do not originate from the same animals and were collected under the national surveillance program for infectious diseases for wild boars, organized by the Swiss Federal Veterinary Office. The first group of samples consisted of various organs originating from 53 animals: spleen, testicles (tissue samples from both testicles of each boar were examined separately), accessory sexual glands, uteri in different stages of gravidity as well as non-gravid uteri samples, lung, and in individual cases penis with prepuce, placenta, kidney, and bladder containing urine. The organs were collected during the hunting seasons of 2001/2002 and 2002/2003 and stored at $-20^{\circ} \mathrm{C}$. Bacterial isolation from the organs was immediately done after the samples arrived to our laboratory. However, and in order to compare bacterial isolation results with these of the real-time PCR, bacterial isolation experiments were repeated and done simultaneously with the real-time PCR three to five years later. The second group of clinical samples consisted of 199 blood samples (in some animals a sero-sanguineous fluid from the thoracic cavity was taken), each from one animal. The sera were separated and examined by serological tests

Table 4: Brucella spp. positive samples detected with IS7 II real-time PCR and serological tests.

\begin{tabular}{lcc}
\hline & Positive samples detected \\
\cline { 2 - 3 } Method & No. & $\%$ \\
\hline IS7 II real-time PCR (only) & 16 & 8.9 \\
IS7 I I real-time PCR and one serological test & 6 & 3.3 \\
IS7 I I real-time PCR and two serological tests & - & - \\
IS7 I I real-time PCR and three serological tests & 2 & I.I \\
\hline
\end{tabular}

In order to simplify the comparison, the six equivocal samples in i-ELISA, four blood samples for which the result was not obtained with RBT, and nine samples inhibited in the real-time PCR were not included in the comparison (total number of blood samples included into the comparison analysis $n=180$ ). 
while the remaining blood clots were frozen at $-20^{\circ} \mathrm{C}$ for one to two years and used for bacterial cultivation and DNA extraction for IS711 real-time PCR analysis.

\section{Bacteriological isolation}

Tissue samples were thawed, the surfaces were heat sterilised and an internal sub-sample was inoculated onto three different nutritive media: Tryptic Soy Agar (TSA) plates containing 5\% sheep blood (Oxoid, Basingstoke, Hampshire, England), Brolac agar (BioMérieux, Genève, Switzerland), and Brucella agar. Brucella agar was made from Brucella medium base (Oxoid) containing 5\% inactivated horse serum with Modified Brucella Selective Supplement (Oxoid, SR0209E), as described in the OIE Manual of Standards for Diagnostic Tests and Vaccines, 2008 [52]. Brolac agar was used in order to facilitate the identification of contaminants growing on the blood plate, which, as expected, were very abundant because the samples were partially autolytic. The cultures were incubated at $37^{\circ} \mathrm{C}$ under an atmosphere with $5 \% \mathrm{CO}_{2}$. Growth and morphology of the colonies were monitored on the second and fifth days after inoculation. For cultivation of blood samples, the leukocyte pellet obtained from $300 \mu \mathrm{l}$ of blood clots (semi-liquid consistency) was inoculated on the plates. Only blood samples that tested positive with the IS711 real-time PCR were used for bacterial cultivation. Suspicious colonies were identified as Brucella spp. based on morphological, cultural and biochemical characteristics, such as oxidase and urease tests. The final species and biovar differentiations were done at the French OIE Reference Laboratory (Agence Française de Sécurité Sanitaire des Aliments, Cedex).

\section{Serological testing}

Sera were tested for antibodies against Brucella using competitive ELISA (SVANOVIR ${ }^{\circledR}$ Brucella-Ab c-ELISA, Svanova Biotech AG Uppsala, Sweden), indirect ELISA (CHEKIT ${ }^{\circledast}$ Brucella suis, Dr. Bommeli AG/Idexx, Switzerland) and Rose Bengal spot agglutination test (RBT) as recommended by the OIE Manual of Standards for Diagnostic Tests and Vaccines, 2008 [52]. The cut-off values for the cELISA and i-ELISA were determined according to the manufacturers' guidelines. Although routinely performed at our institute, complement fixation test (CFT) is not adequate as a confirmatory test for haemolytic sera of wild boars from the hunting bag and therefore could not be used for these samples.

\section{DNA extraction from clinical samples}

DNA from 25 to $30 \mathrm{mg}$ of tissue (or $10 \mathrm{mg}$ of spleen) and $100 \mu \mathrm{l}$ of liquid samples, such as amniotic fluid and urine, were extracted using the QIAamp ${ }^{\circledast}$ DNA Mini Kit (QIAGEN, Basel, Switzerland) according to the manufacturer's tissue protocol. For the DNA extraction from blood samples, only the leukocyte pellet was used. Briefly, $300 \mu \mathrm{l}$ of blood clots (semi-fluid consistency) was resuspended in $600 \mu \mathrm{l}$ erythrocyte lysis buffer $\left(1.55 \mathrm{M} \mathrm{NH}_{4} \mathrm{Cl}, 0.1 \mathrm{M}\right.$ $\mathrm{KHCO}_{3}, 1 \mathrm{mM}$ Titriplex III, $10 \times$ conc.) and $300 \mu \mathrm{l}$ PBS buffer. The suspension was mixed, incubated for $10 \mathrm{~min}$ utes and centrifuged at $8000 \mathrm{rpm}$ for 2 minutes. The supernatant was discarded and the treatment with erythrocyte lysis solution was repeated until the leukocyte pellets lost all reddish colouring. The DNA from the leukocyte pellet was extracted following the tissue protocol of the QIAamp ${ }^{\circledast}$ DNA Mini Kit (QIAGEN). The TaqMan $^{\circledast}$ Ribosomal RNA Control Reagent (Applied Biosystems, Foster City, CA, USA) designed to detect the $18 \mathrm{~S}$ ribosomal RNA (rRNA) gene highly conserved among a diverse group of eukaryotes was used as an endogenous control of DNA extraction.

\section{IS7 I I real-time PCR}

The primers and TaqMan ${ }^{\otimes}$ probe selected from the sequences of the IS711 element and used for amplification and detection were described previously by Hiniæ and colleagues [46]. Briefly, real-time amplifications were performed using $2.5 \mu \mathrm{l}$ of DNA extract, $300 \mathrm{nM}$ of each primer, $200 \mathrm{nM}$ probe and TaqMan ${ }^{\circledast}$ Universal PCR Master Mix, No AmpErase ${ }^{\circledast}$ UNG (Applied Biosystems) in a $25-\mu l$ volume. An exogenous Internal Positive Control (IPC, Applied Biosystems) was added to each reaction, according to the manufacturer's protocol, in order to check for the presence of PCR inhibitors. Amplification and real-time fluorescence detection was performed on a TaqMan $^{\circledast} 7500$ Real-time PCR system (Applied Biosystems) according to the standard protocol. A positive result was indicated by fluorescence above a threshold of 0.06 with the auto settings used for the baseline.

\section{Quantification of bacteria}

The TaqMan ${ }^{\circledast}$ Ribosomal RNA Control Reagent (Applied Biosystems) designed to detect the $18 \mathrm{~S}$ ribosomal RNA (rRNA) gene was used as an endogenous extraction control and for quantification of host cells. The quantification of bacteria per host cell in various organs was done using the standard curve method (User's Manual, ABI PRISM 7700 Sequence Detection System, Applied Biosystems).

\section{Authors' contributions}

VH carried out the experimental work, performed the analysis of the results and drafted the manuscript. IB and AT participated in the identification of bacterial isolates. MH performed RBT and i-ELISA. RM participated in the design of the study and helped in the interpretation of the results. CA conceived the study, participated in its design and coordination, and helped to draft the manuscript. All authors read and approved the final manuscript.

\section{Acknowledgements}

This study was financed by the Swiss Federal Veterinary Office (Grant no. 1.06.02). We want to thank Dr. Patrick Boujon for his contribution in the 
Brucella isolation from tissue samples, Prof. Dr. Joachim Frey and Dr. Edy $M$. Vilei for intellectual contribution and critical review of the results, and Dr. Bozena Korczak for support in sequencing.

\section{References}

I. Cvetnic Z, Toncic J, Spicic S, Lojkic M, Terzic S, Jemersic L, Humsk A, Curic S, Mitak M, Habrun B, et al.: Brucellosis in wild boar (Sus scrofa) in the Republic of Croatia. Veterinarni Medicina 2004 49: $115-122$.

2. Leuenberger R, Boujon P, Thür B, Miserez R, Garin-Bastuji B, Rüfenacht J, Stärk KD: Prevalence of classical swine fever, Aujeszky's disease and brucellosis in a population of wild boar in Switzerland. Vet Rec 2007, 160:362-368.

3. Köppel C, Knopf L, Ryser M-P, Miserez R, Thür B, Stärk KDC: Serosurveillance for selected infectious disease agents in wild boars (Sus scrofa) and outdoor pigs in Switzerland. Eur J Wild Res 2007, 53:212-220

4. Bricker BJ: PCR as a diagnostic tool for brucellosis. Vet Microbiol 2002, 90:435-446.

5. Navarro E, Casao MA, Solera J: Diagnosis of human brucellosis using PCR. Expert Rev Mol Diagn 2004, 4: I I5-123.

6. Al Dahouk S, Nöckler K, Tomaso H, Splettstoesser WD, Jungersen G, Riber U, Petry T, Hoffmann D, Scholz HC, Hensel A, et al:: Seroprevalence of brucellosis, tularemia, and yersiniosis in wild boars (Sus scrofa) from north-eastern Germany. J Vet Med B Infect Dis Vet Public Health 2005, 52:444-455.

7. Watarai $M$, Ito $N$, Omata $Y$, Ishiguro $N$ : A serological survey of Brucella spp. in free-ranging wild boar (Sus scrofa leucomystax) in Shikoku, Japan. J Vet Med Sci 2006, 68: I I39-I I4 I.

8. Vengust G, Valencak $Z$, Bidovec A: A serological survey of selected pathogens in wild boar in Slovenia. J Vet Med B Infect Dis Vet Public Health 2006, 53:24-27.

9. Ruiz-Fons $F$, Vicente J, Vidal D, Höfle U, Villanúa $D$, Gauss $C$, Segalés J, Almería S, Montoro V, Gortázar C: Seroprevalence of six reproductive pathogens in European wild boar (Sus scrofa) from Spain: the effect on wild boar female reproductive performance. Theriogenology 2006, 65:73 I-743.

10. Kittelberger R, Hilbink F, Hansen MF, Ross GP, Joyce MA, Fenwick S, Heesemann J, Wolf-Watz H, Nielsen K: Serological crossreactivity between Brucella abortus and Yersinia enterocolitica 0:9 - II the use of Yersinia outer proteins for the specific detection of Yersinia enterocolitica infections in ruminants. Vet Microbiol | 995, 47:27|-280.

II. Godfroid J, Saegerman C, Wellemans V, Walravens K, Letesson J-J, Tibor A, Mc MA, Spencer S, Sanna M, Bakker D, et al:: How to substantiate eradication of bovine brucellosis when aspecific serological reactions occur in the course of brucellosis testing. Vet Microbiol 2002, 90:46I-477.

12. Al Dahouk S, Nöckler K, Scholz HC, Tomaso H, Bogumil R, Neubauer H: Immunoproteomic characterization of Brucella abortus III 9-3 preparations used for the serodiagnosis of Brucella infections. J Immunol Methods 2006, 309:34-47.

13. Muñoz PM, Marín CM, Monreal D, González D, Garin-Bastuji B, Díaz R, Mainar-Jaime RC, Moriyón I, Blasco JM: Efficacy of several serological tests and antigens for diagnosis of bovine brucellosis in the presence of false-positive serological results due to Yersinia enterocolitica O:9. Clin Diagn Lab Immunol 2005, |2:|4|-|5|.

14. Weynants V, Gilson D, Cloeckaert A, Tibor A, Denoel PA, Godfroid F, Limet JN, Letesson JJ: Characterization of smooth lipopolysaccharides and $O$ polysaccharides of Brucella species by competition binding assays with monoclonal antibodies. Infect Immun 1997, 65:1939-1943.

15. Zerva L, Bourantas K, Mitka S, Kansouzidou A, Legakis NJ: Serum is the preferred clinical specimen for diagnosis of human brucellosis by PCR. J Clin Microbiol 200I, 39:166I-1664.

16. Al Dahouk S, Tomaso H, Nöckler K, Neubauer H, Frangoulidis D: Laboratory-based diagnosis of brucellosis - a review of the literature. Part II: serological tests for brucellosis. Clin Lab 2003, 49:577-589.

17. Tessaro SV, Forbes LB: Experimental Brucella abortus infection in wolves. J Wild Dis 2004, 40:60-65.

18. Carpenter PL: Immunology and serology Philadelphia, PA: W. B. Saunders Company; 1975.
19. Leal-Klevezas DS, Martínez-Vázquez IO, García-Cantú J, LópezMerino A, Martínez-Soriano JP: Use of polymerase chain reaction to detect Brucella abortus biovar $I$ in infected goats. Vet Microbiol 2000, 75:9l-97.

20. Tittarelli M, di Ventura M, de Massis F, Petrini A, Giovannini A, Nannini $D$, Caporale $V$ : Kinetics of the antibody response in ewes experimentally infected with Brucella melitensis biovar 3. Veterinaria Italiana 2007, 40:5-10.

2I. Gardner IA, Stryhn H, Lind P, Collins MT: Conditional dependence between tests affects the diagnosis and surveillance of animal diseases. Prev Vet Med 2000, 45: 107-122.

22. Godfroid J: Brucellosis in wildlife. Rev Sci Tech 2002, 21:277-286.

23. Herman L, De RH: Identification of Brucella spp. by using the polymerase chain reaction. Appl Environ Microbiol 1992 , 58:2099-2I0I.

24. Rijpens NP, Jannes G, Van Asbroeck M, Rossau R, Herman LM: Direct detection of Brucella spp. in raw milk by PCR and reverse hybridization with I6S-23S rRNA spacer probes. Appl Environ Microbiol 1996, 62:1683-1688.

25. Leal-Klevezas DS, Lopéz-Merino A, Martínez-Soriano JP: Molecular detection of Brucella spp.: rapid identification of B. abortus biovar I using PCR. Arch Med Res 1995, 26:263-267.

26. Baily GG, Krahn JB, Drasar BS, Stoker NG: Detection of Brucello melitensis and Brucella abortus by DNA amplification. J Trop Med Hyg 1992, 95:27I-275.

27. Leal-Klevezas DS, Martínez-Vázquez IO, López-Merino A, MartínezSoriano JP: Single-step PCR for detection of Brucella spp. from blood and milk of infected animals. I Clin Microbiol 1995, 33:3087-3090.

28. Queipo-Ortuño MI, Morata P, Ocón P, Manchado P, Colmenero JD: Rapid diagnosis of human brucellosis by peripheral-blood PCR assay. J Clin Microbiol I 997, 35:2927-2930.

29. Cetinkaya B, Ongor H, Muz A, Ertas HB, Kalender H, Erdogan HM: Detection of Brucella species DNA in the stomach content of aborted sheep fetuses by PCR. Vet Rec 1999, I44:239-240.

30. Amin AS, Hamdy ME, Ibrahim AK: Detection of Brucella melitensis in semen using the polymerase chain reaction assay. Vet Microbiol 200I, 83:37-44.

31. Navarro E, Escribano J, Fernandez J, Solera J: Comparison of three different PCR methods for detection of Brucella spp in human blood samples. FEMS Immunol Med Microbiol 2002, 34:|47-|5|.

32. Hamdy ME, Amin AS: Detection of Brucella species in the milk of infected cattle, sheep, goats and camels by PCR. Vet J 2002, 163:299-305.

33. Leyla G, Kadri G, Umran O: Comparison of polymerase chain reaction and bacteriological culture for the diagnosis of sheep brucellosis using aborted fetus samples. Vet Microbiol 2003, 93:53-61.

34. Elfaki MG, Uz-Zaman T, Al-Hokail AA, Nakeeb SM: Detection of Brucella DNA in sera from patients with brucellosis by polymerase chain reaction. Diagn Microbiol Infect Dis 2005, 53:1-7.

35. Keid LB, Soares RM, Vasconcellos SA, Chiebao DP, Megid J, Salgado $V R$, Richtzenhain LJ: A polymerase chain reaction for the detection of Brucella canis in semen of naturally infected dogs. Theriogenology 2007, 67: 1203-1210.

36. Romero C, Pardo M, Grillo MJ, Diaz R, Blasco JM, Lopez-Goñi I: Evaluation of PCR and indirect enzyme-linked immunosorbent assay on milk samples for diagnosis of brucellosis in dairy cattle. J Clin Microbiol 1995, 33:3198-3200.

37. Newby DT, Hadfield TL, Roberto FF: Real-time PCR detection of Brucella abortus: a comparative study of SYBR green I, 5'exonuclease, and hybridization probe assays. Appl Environ Microbiol 2003, 69:4753-4759.

38. Probert WS, Schrader KN, Khuong NY, Bystrom SL, Graves MH: Real-time multiplex PCR assay for detection of Brucella spp., B. abortus, and B. melitensis. J Clin Microbiol 2004, 42:I290-I 293.

39. Bogdanovich T, Skurnik M, Lübeck PS, Ahrens P, Hoorfar J: Validated 5' nuclease PCR assay for rapid identification of the genus Brucella. J Clin Microbiol 2004, 42:226I-2263.

40. Colmenero JD, Queipo-Ortuño MI, Reguera JM, Baeza G, Salazar JA, Morata P: Real time polymerase chain reaction: a new powerful tool for the diagnosis of neurobrucellosis. J Neurol Neurosurg Psychiatry 2005, 76: 1025-1027. 
4l. Debeaumont C, Falconnet PA, Maurin M: Real-time PCR for detection of Brucella spp. DNA in human serum samples. Eur J Clin Microbiol Infect Dis 2005, 24:842-845.

42. Queipo-Ortuño MI, Colmenero JD, Baeza G, Morata P: Comparison between LightCycler Real-Time Polymerase Chain Reaction (PCR) assay with serum and PCR-enzyme-linked immunosorbent assay with whole blood samples for the diagnosis of human brucellosis. Clin Infect Dis 2005, 40:260-264.

43. Queipo-Ortuño MI, Colmenero JD, Reguera JM, García-Ordoñez MA, Pachón ME, Gonzalez M, Morata P: Rapid diagnosis of human brucellosis by SYBR Green I-based real-time PCR assay and melting curve analysis in serum samples. Clin Microbiol Infect 2005, I I:7|3-7|8.

44. Queipo-Ortuño MI, Colmenero JD, Muñoz N, Baeza G, Clavijo E, Morata P: Rapid diagnosis of Brucella epididymo-orchitis by real-time polymerase chain reaction assay in urine samples. J Urol 2006, I 76:2290-2293.

45. O'Leary S, Sheahan M, Sweeney T: Brucella abortus detection by PCR assay in blood, milk and lymph tissue of serologically positive cows. Res Vet Sci 2006, 8 I: |70-176.

46. Hinic V, Brodard I, Thomann A, Cvetnic Z, Makaya PV, Frey J, Abril $C:$ Novel identification and differentiation of Brucella melitensis, B. abortus, B. suis, B. ovis, B. canis, and B. neotomae suitable for both conventional and real-time PCR systems. J Microbiol Meth 2008, 75:375-378.

47. Vemulapalli R, McQuiston JR, Schurig GG, Sriranganathan N, Halling SM, Boyle SM: Identification of an IS7 I I element interrupting the wboA gene of Brucella abortus vaccine strain RB5 I and a PCR assay to distinguish strain RB5 I from other Brucella species and strains. Clin Diagn Lab Immunol 1999, 6:760-764.

48. Moreno E, Cloeckaert A, Moriyón I: Brucella evolution and taxonomy. Vet Microbiol 2002, 90:209-227.

49. Morata P, Queipo-Ortuño MI, de Dios Colmenero J: Strategy for optimizing DNA amplification in a peripheral blood PCR assay used for diagnosis of human brucellosis. J Clin Microbiol 1998, 36:2443-2446.

50. Elfaki MG, Al-Hokail AA, Nakeeb SM, Al-Rabiah FA: Evaluation of culture, tube agglutination, and PCR methods for the diagnosis of brucellosis in humans. Med Sci Monit 2005, I I:MT69-MT74.

5I. Ilhan Z, Aksakal A, Ekin IH, Gülhan T, Solmaz H, Erdenlig S: Comparison of culture and PCR for the detection of Brucella melitensis in blood and lymphoid tissues of serologically positive and negative slaughtered sheep. Lett Appl Microbiol 2008, 46:30I-306.

52. Office International des Epizooties OIE: Manual of standards for diagnostic tests and vaccines Paris: Office International des Epizooties O.I.E; 2008.
Publish with Bio Med Central and every scientist can read your work free of charge

"BioMed Central will be the most significant development for disseminating the results of biomedical research in our lifetime. "

Sir Paul Nurse, Cancer Research UK

Your research papers will be:

- available free of charge to the entire biomedical community

- peer reviewed and published immediately upon acceptance

- cited in PubMed and archived on PubMed Central

- yours - you keep the copyright
BioMedcentral 